Gadjah Mada International Journal of Business

May-August 2008, Vol. 10, No. 2, pp. 211-235

\title{
TRUST IN ORGANIZATIONAL AND WORKPLACE DEVIANT BEHAVIOR The Moderating Effect of Locus of Control
}

\author{
Abdul Rahman Abdul Rahim \\ Aizzat Mohd. Nasurdin
}

This study seeks to investigate the moderating role of locus of control (LOC) in the relationship between trust in organization (TiO) and workplace deviant behavior (WDB). Three forms of deviant behavior are identified: interpersonal deviance, production deviance, and property deviance. The regression analyses carried out on a sample of 355 employees show mixed results. Trust in organization ( $\mathrm{TiO}$ ) demonstrates a negative relationship with production deviance and property deviance. In contrast, trust in organization (TiO) is positively related to interpersonal deviance. Furthermore, locus of control ( $L O C$ ) is found to moderate the relationship between trust in organization (TiO) and deviant behaviors. Implications, limitations, and suggestions for future research are discussed.

Keywords: interpersonal deviant behavior; locus of control; Malaysia; property deviant behavior; trust in organization 
Gadjah Mada International Journal of Business, May - August 2008, Vol. 10, No. 2

\section{Introduction}

Workplace is an opportunity for the expression of various forms of behavior that affect individuals, organizations, and society. Although some of the behavior is socially desirable (such as helping and citizenship behavior), others may be viewed as inappropriate or outside the normal principles of acceptability. The inappropriate or unacceptable behavior such as stealing, withholding efforts, absenteeism, abusing sick day privileges have been labeled by researchers (such as Appelbaum et al. 2005; Bennett and Robinson 2000; Diefendorff and Mehta 2007; Hollinger 1986) as workplace deviant behavior.

According to Henle et al. (2005), nearly 95 percent of all companies report some deviance-related experience within their respective organizations. This line of argument is supported by Harper (1990) as cited in Robinson and Bennett (1995), who estimate that 33 to 75 percent of employees have engaged in at least one form of deviant behavior such as theft, computer fraud, embezzlement, vandalism, sabotage and absenteeism. Added to these, researchers such as Aquino, Galperin and Bennett (2004), Bolin and Heartherly (2001), Giacalone et al. (1997), Sackett and Devore (2001), and Vardi and Weitz (2004) indicate that workplace deviant behavior can range in terms of severity from minor to serious offence. Some acts are considered serious such as company property theft, sabotage, drugs and alcohol abuse, while others are more minor such as taking excessive breaks, wasting resources, blaming others, and gossiping about peers.

Workplace deviance has been considered injurious to both the organization and human welfare (Griffin and O’Leary-Kelly 2004). Apart from reducing the firm's profit margin, victims of deviant acts will experience lower morale(Robinson and Greenberg 1998). Evidence has shown that the amount of losses arising from misconducts at the workplace is huge. For example, employee theft has been reported to be ten times costlier than the street crime and has been blamed for 30 percent to 50 percent of all business failures in the United States of America (Snyder and Blair 1989). On a similar note, Greenberg and Tomlinson (2004) claim that petty thieves account for more business losses than grand theft in an organization. These substantial costs have generated growing interests among researchers especially from the West concerning deviant behavior in organization.

In Malaysia, the phenomenon of workplace deviant behavior has been given a great deal of attention. This is evident from the frequency of reports in newspapers and other public media concerning cases involving dishonesty, poor work attitudes (New Straits Times 2005), fraudulence, (Utusan Malaysia 2004), and the issue of fake medical certificate (Utusan Malaysia 2003). Besides, a review of the dismissal cases under the purview of the Malaysian Industrial Relations Department from 
year 2000 to 2005 indicates the presence of a variety of deviant behavior among Malaysian employees (The Malaysian Current Law Journal 2000 -2005). Although the number of cases is not alarming, this does not mean that employees' acts of deviance are declining. Given the fact that incidences of employee misbehavior would tarnish the image of the particular organization, many incidences of deviance go unreported as argued by Atkinson (2000). Being one of the largest sectors of the Malaysian economy (Ninth Malaysia plan 2006-2010, 2006), the manufacturing sector should be highly concerned with work deviance. Since local studies in this area are scarce, there is a need for investigation on the predictors of deviant behavior within the Malaysian manufacturing context.

Past studies have examined various antecedents of employee deviant behavior. These variables can be categorized under personal, organizational, work-related, and environmental factors. Personal variables encompass individual differences, attitudes, and personality traits (for example, Bolin and Heatherly 2001; Colbert et al. 2004; Douglas and Martinko 2001; Raelin 1984; Vardi and Werner 1996). Organizational variables include perceived support, organizational justice, leadership style, psychological contract violation, organizational climate, and organizational politics (Colbert et al. 2004; Giacalone and Greenberg 1997; Lau, Au, and Ho 2003; Turnley and Feldman 1999; Vigoda 2002). Work-related variables include work stressors and job attributes (Chen and Spector 1991; Fox et al. 2001; Ganster and Shaubrouk 1991; Lau et al. 2003). Environmental factors are comprised of culture, ethical infrastructure, organizational constraints, and environmental uncertainty (Allen et al. 2005; Carmeli 2005; Greenberg 2002; Spector and Fox 2001; Vardi 2001). Given that attitude is a prelude to behavior, one would expect positive work attitudes to have a mitigating effect on deviant behavior. The importance of work attitudes on work behaviors have been noted by previous scholars (Ackroyd and Thompson 1999; Vardi and Weitz 2004). One form of attitude that influences employees' behavior at work is trust in organization (Kramer, Brewer and Hana 1996). Trust is central to human relationships as argued by Nooteboom (2003). Anindividual's trust in an organization may deteriorate if the organization fails to fulfill its promises, which in turn, may lead to negative behavior such as workplace deviance(Bies and Tripp 1996; Brown and Trevino 2003). However, many researchers (such as Brown and Trevino 2003; Grover 1997) have highlighted the need for more empirical evidence of the relationship between trust and deviant behavior. Thus, the first objective of this study is to examine the effect of trust in organization on workplace deviant behavior. Studies (Salancik and Pfeffer 1978; Vardi and Werner 1996) have shown that an individual's attitude-behavior relationship is contingent upon one's personality trait. One such characteristic re- 
Gadjah Mada International Journal of Business, May - August 2008, Vol. 10, No. 2

lates to locus of control. Those with internal locus of control believe in their own efforts and abilities, and are more likely to take initiative and display a wider set of work behavior than what is specified by the job (Withey and Cooper 1989). Meanwhile, those with an external locus of control believe that work outcomes are dependent upon external factors such as fate and luck, and as such, are more likely to modify their environment and increase their feeling of control through destructive acts (Allen and Greenberg 1980). Hence, the second aim of this research is to investigate the role of locus of control in moderating the relationship between trust in organization and deviant behavior.

\section{Workplace Deviant Behavior}

Workplace deviant behavior (WDB) refers to "the voluntary behavior that violates significant organizational norms, and in doing so threatens the well-being of an organization, its members or both" (Robinson and Bennett 1995). Examples of such behavior include absenteeism (Johns 1997), theft (Greenberg 1997), and sexual harassment (Paetzold 2004). Researchers have used different terms to denote these deviant behavior such as organizational misbehavior (Ackroyd and Thompson 1999), organizational retaliation behavior (Skarlicki and Folger 1997), antisocial behavior (Giacalone and Greenberg 1997), counterproductive behavior (Marcus and Schuler 2004), and work- place aggression (Baron and Neuman 1998).

Regardless of the different terminologies, Robinson and Bennett (1995) propose that WDB can vary based on its target: organizational and individual. Organizational deviance (WDBO) encompasses deviant behavior targeted toward the organization (e.g., intentionally working slowly, damaging company property, sharing confidential company information), while interpersonal deviance (WDBI) encompasses deviant behavior targeted toward individuals (e.g., violence, gossip, and theft from coworkers). Organizationally-focused deviant behavior can be further categorized into property deviance and production deviance. Property deviance refers to incidences where employee violates the organizational norms by acquiring or damaging the organization's tangible assets. Production deviance refers to employee behavior that violates organizational norms with regard to the quality and quantity of work to be accomplished. Individually-focused deviant behavior is categorized as political deviance and personal aggression. Political deviance refers to behavior that causes other individuals a political disadvantage. Personal aggression reflects acts of hostility toward other individuals. Following past studies, this study conceptualizes WDB based on its target: organizational deviance (WDBO) and interpersonal deviance (WDBI). It is important to differentiate between WDBO and 
Rahim \& Nasurdin-Trust in Organizational and Workplace Deviant Behavior

WDBI because while the former deals with behavior between the individual and the organization, the latter focuses on behavior among organizational members. This delineation will provide more focus and specificity to the study and prophecy of such behavior, leading to the development of more systematic and integrative theories of WDB.

\section{Trust and Workplace Deviant Behavior}

Trust is important because of its centrality in human relationship (Cook 2005; Lewicki and Bunker 1996; Nooteboom 2003). Trust that develops from general beliefs about expectations is closely related to one's willingness to trust others during the interaction process. Such interactions will develop relationships in social and organizational lives that go beyond economic interests (Lewicki and Bunker 1996). These relationships are portrayed in terms of mutual obligations, respect, and goodwill (Nooteboom 2003). Trust is an attitude held by individuals in relation to another individual or group of individuals, and it is very important in working relationship (Costa 2003). For the purpose of this study, trust in organization (TiO) is viewed as “one's expectations, assumptions, or beliefs for the organization actions that will influence the likelihood of the employee's future actions" (Gabarro and Athos 1976; Robinson and Rousseau 1994). If the organization breaks on a promise, the organization's integrity is questioned.
As a result, employees' trust toward the organization may decline.

Organizational behavioral studies have illustrated that trust is a feature of relationship that forms over time (Robbins 2003; McShane and Glinow 2003). Some scholars (Dreu, Giebels and Vliert 1998; Robinson and Rousseau 1994) suggest that reciprocity in exchange relations enhances trust, while the absence or violation of reciprocity erodes it. Lack of trust will make an employee feels tense, unsatisfied, less emotionally committed, and may become unproductive (Costa et. al. 2001), resulting in variety of responses ranging from confrontation to social withdrawal such as withholding supports, working less, or leaving the organization (Bies and Tripp 1996). This is because when an employee perceives the existence of unjustness or inequity in their employment relationship, he or she attempts to restore balance and equity through their actions (Adams 1965).

Previous studies have demonstrated a significant and positive relationship between trust and work attitude such as job satisfaction and commitment (Gilder 2003; Goris et al. 2003; Konovsky and Cropanzano 1991; Wong et al. 2002). On the other hand, job satisfaction and commitment are found to have a significant and negative relationship with deviant behavior at work (Lau et al. 2003; Tepper 2000; Vigoda 2002). Empirical evidence also reveals a negative and significant relationship between trust and intention to leave the organization 
Gadjah Mada International Journal of Business, May - August 2008, Vol. 10, No. 2

(Ferres et al. 2005; Konovsky and Cropanzano 1991). Consequently, intention to leave will lead employees to engage in deviant behavior at work (Bolin and Heatherly 2001; Spector and Jex 1991). Trust is also found to have a significant and negative relationship with employee's efforts withholding, information distortion (Robert and O'Reily 1974), procrastination, withdrawal, absenteeism and little effort at work (Gilder 2003; Deery et al. 2006; Rusbult et al. 1988). Gilder (2003) discovers that trust in organization has a negative and significant correlation with destructive behavior such as exit, voice, negligence, commitment to personal affairs, and intent to leave the organization. Therefore, when trust in organization is low, employees' cooperation toward the organization will also decline (Deery et al. 2006). When the employment relationship is perceived to be negative, employees show a greater level of resentment toward the organization. As a result, they will be more likely to engage in deviant behavior detrimental to the organization (Bies and Tripp 1997) and their interpersonal relationships within the organization (Perry and Mankin 2004; Premeaux and Bedeian 2003). Following this line of thought, and given that there are two forms of deviant behavior, it is hypothesized that:

H1: Trust in organization is negatively and significantly related to WDB (WDBI, WDBO).
H1a: Trust in organization is negatively and significantly related to interpersonal deviance (WDBI).

$H 1 b$ : Trust in organization is negatively and significantly related to Organizational deviance (WDBO).

\section{Locus of Control}

Locus of control (LOC) is an important individual factor, and can be regarded as a stable personality trait (Lu, Wu and Cooper 1999). LOC refers to a generalized belief that rewards, reinforcement or outcomes of life are controllable, either by one's own actions or by outside factors (Spector 1988). Those with an internal LOC (internals) believe that work outcomes are based on their own efforts and abilities. On the other hand, those with an external work LOC (externals) believe that work outcomes depend on external factors, such as fate, luck or professional acquaintances.

The type of locus of control in people has implications for behavior in work settings. Withey and Cooper (1989) argue that internals believe that their actions make a difference and accordingly are more likely to take initiative and display a wider set of work behavior than what is specified by the job. As such, internals are more likely to exhibit greater intrinsic motivation, have higher job satisfaction, and experience better work-related well-being (Allen et al. 2005), and will 
Rahim \& Nasurdin-Trust in Organizational and Workplace Deviant Behavior

respond negatively to frustration (Storms and Spector 1987). According to Spector and O’Connell (1994), internals usually use their job-relevant experience to improve tasks and outputs by obtaining and utilizing information more effectively. Hence, internals exert greater efforts personally to control their environment (Blau 1987). In contrast, externals are less likely either to think about learning a job or to actually leave even if they are dissatisfied with certain aspects of it (Blau 1987). Externals may attempt to modify their environment and increase their feeling of control through destructive acts (Allen and Greenberg 1980). Externals report more uncontrollable stressors at work than do internals (Lu, Wu and Cooper 1999). Chiu et al. (2005) empirically demonstrate that the externals' inability to cope with job stress negatively influences their organizational commitment and job satisfaction.

Findings on the effects of LOC on work attitudes and outcomes have been inconclusive. Firth et al. (2004) fail to identify LOC as having a significant effect in mediating the relationship between work-stressors and employees' intention to quit. Similarly, Gable and Dangello (1994) are not able to establish any relationship between LOC and managerial job performance. Gable and Dangello (1994) empirically demonstrate that LOC serves to moderate the relationship between Machiavellianism and managerial job performance. Chiu et al. (2005) find that the negative relationship between job satisfaction and turnover intention is stronger for internals than externals. Although Lonergan and Maher (2000) propose that LOC is related to one's reactions to the work environment, they fail to prove the moderating role of LOC in the relationship between job characteristics and procrastination. Storms and Spector (1987) discover that LOC moderates the frustrationsabotage relationship. It is found that frustrated externals tend to engage in sabotage while frustrated internals do not. Meanwhile, Blau (1987) in his study discovers that LOC moderates the relationship between withdrawal cognition and turnover. Internals show a significantly stronger positive relationship than do externals between withdrawal cognition and turnover. Hegarty and Sims (1978 1979) find mixed results concerning the measures of LOC and unethical behavior. Externals are found to be associated with unethical behavior in their initial study in 1978. However, in another study, Hegarty and Sims (1979) find no significant relationship between externals and unethical behavior. Similarly, Jones and Kavanagh (1996) report inconsistent results based on two experiments conducted on LOC and unethical behavior intention. In the first experiment, it is found that individuals with an external LOC report higher unethical behavior intentions than do internals, but not in the second experiment. Meanwhile, Reiss and Mitra (1988) demonstrate that externals perceive unethical behavior as acceptable behavior, whereas internals perceive 
it as unacceptable. The above discussion suggests that LOC may serve as potential moderator in the employee's attitude-behavior relationship.

According to scholars (Costa 2003; Nooteboom 2003; Robbins 2003), trust (in organization) is personal and relational in nature. The personal and relational characteristics of trust toward the organization suggest that the strength of the relationship between an individual's trust in the employing organization and his/ her work outcomes (such as WDB) may be dependent upon the person's personality traits (such as LOC). Several researchers have examined the moderating role of LOC between attitude and behavior (Cherry and Fraedrich 2000; Gable and Dangello 1994; Lonergan and Maher 2000; Storms and Spector 1987). Previous studies (such as Cherry and Fraedrich 2000; Robert et al. 1997; Syrotnick and D'Arcy 1982) have provided empirical evidence of the existence of differences in coping style between internal and external LOC individuals. Furthermore, Zahra (1989) demonstrate that executives who have an external LOC are inclined to perceive organizational politics as more ethical than those with an internal LOC. Robinson and Bennett (1995) view organizational politics as a form of interpersonal deviant. According to Zahra (1989), external LOC individuals tend to have a positive relationship with WDB. In contrast, Banai et al. (2004) find a significant and negative relationship between internal LOC in- dividuals and work alienation. Work alienation is an act to reduce work involvement, and has been perceived as an act of deviance at work (Harris 2004; O’Leary-Kelly and Griffin 2004). Therefore, this study postulates that LOC will moderate the relationship between one's trust in organization and his/her WDB. Hence, our second hypothesis is:

H2: Locus of control moderates the relationship between trust in organization (TiO) and WDB (WDBO, WDBI). Specifically, the negative relationship between trust in organization (TiO) and WDB (WDBI, WDBO) is stronger for individuals with internal LOC than individuals with external LOC.

H2a: The negative relationship between TiO and WDBI is stronger for individuals with internal LOC than individuals with external LOC.

$H 2 b$ : The negative relationship between TiO and WDBO is stronger for individuals with internal LOC than individuals with external LOC.

\section{Methodology}

\section{Sample}

Respondents are comprised of 355 production employees of large manufacturing companies affiliated with the Federation of Malaysian Manufacturer. The production employees consist of 286 production operators, 30 produc- 
tion line leaders/assistant supervisors, and 39 production technicians. Meanwhile, 74 supervisors participate in the survey, where 61 of them hold production supervisor positions and 13 hold production technical supervisor positions. This study is focused on large companies since previous studies (Lau et al. 2003), Mitchell et al. 1996) have shown that large organizations have more incidences of deviant behavior. This line of argument is further supported by other scholars (such as Meier and Bohie 2000; McManus 2007; Mitchell et al. 1996; Wooward 1980) who claim that large manufacturing companies are more likely to have a wider span of control that will lead to lack of supervision and ambiguous standards.

\section{Measures}

The two forms of WDB are gauged via supervisory ratings. 27 items developed by Robinson and Bennett (1995) are used. Items are scored on a 7-point likert scale ranging from $1=$ 'never' to 7 = 'more than 15 times'. Complying with Hair et al., (2006), a factor analysis is conducted and the results reveal three dimensions of WDB: interpersonal deviance, production deviance, and property deviance.

WDB targeted at individuals is classified as interpersonal deviance (WDBI). Examples include playing a mean prank, making fun and publicly embarrassing others. Production deviance (WDBPn) is a form of deviant behavior targeted at the organization that which will ultimately deteriorate the quality and quantity of work to be done. Examples include taking longer break, leaving unfinished work, taking unnecessary sick leaves, and intentionally working slowly. Property deviance (WDBPr) may cause damage to the organization's assets. It involves actions such as falsifying information, taking and using company's properties illegally. The responses can range from 1 = "strongly disagree" to 7 = "strongly agree”. The Cronbach's alpha for all the three dimensions ranges from 0.79 to 0.82 .

The independent variable, trust in organization (TiO), is measured using seven items derived from Gabarro and Anthons (1976). The seven items are slightly modified to suit the purposes of this study (whereby the word "employer" is replaced with "organization”). Sample items include, "I am not sure that I fully trust my organization" and "My organization is not always honest and trustworthy". These items are reverse-coded before conducting further analysis. The responses can range from 1 = "strongly disagree" to "7 = strongly agree”. The Cronbach's alpha for this dimension is 0.76 .

Locus of control (LOC), the moderating variable, is measured using eight items used in Martin et al.'s (2005) study. These items are originally designed by Spector (1988). The responses can range from 1 = "strongly disagree" to " 7 = strongly agree”. This single dimension has a reliability coefficient of 0.56. Based on Ary et al. (2006) whose minimum acceptable reliability level is .50 for an explor- 
atory study, we opt to retain this variable.

\section{Method of Analysis}

The hypotheses of the study are tested via multiple hierarchical regressions (Hair et al. 2006). Previous studies have shown that gender, age, tenure, and job position are significant predictors of WDB (Douglas and Martinko 2001; Lau et al. 2002; Martinko et al. 2002; Thoms et al. 2001). Hence, these four demographic variables are controlled in the statistical analysis.

\section{Results}

\section{Sample Profile}

A total of 355 respondents (subordinates) participate in this survey where 59.4 percent are males and 40.6 percent are females. 56 percent (198) of them are married. The average age for the sample is 30.19 years $(\mathrm{SD}=6.9$ years). Approximately 64.5 percent have educational qualification up to secondary school level, and the remaining respondents (35.5\%) have certificates, diplomas, or degree quali- fications. In terms ethnicity, majority of the subordinates are Malay (84.5\%), followed by Chinese (6.5\%), Indian (6.2\%), and others (2.8\%). The respondents' average organizational tenure is 7.93 years ( $\mathrm{SD}=6.2$ years).

The average age of the supervisors is 35.2 years ( $\mathrm{SD}=6.3$ years) and 84.2 percent of them are married. A majority of the supervisors are male (79.7\%). In terms of educational qualification, 32.9 percent of the supervisors possess secondary school level qualification, 24.8 percent hold diplomas, 35.5 percent have bachelor degrees and 6.7 percent have other qualifications. Majority of the supervisors are Malay (74.1\%), followed by Indian (14.6\%) and Chinese (11.3\%). Their average organizational tenure is 9.7 years $(\mathrm{SD}=7.1$ years $)$.

\section{Descriptive Statistics, Intercorrelations, and Reliabilities}

The means, standard deviations, intercorrelations, and reliabilities for the measures used in the study are reported in Table 1.

Table 1. Descriptive Statistics, Correlations, and Reliabilities

\begin{tabular}{|c|c|c|c|c|c|c|c|c|}
\hline & Mean & SD & WDBI & WDBPn & WDBPr & TiO & LOC & \\
\hline WDBI & 1.36 & 0.69 & 1 & $(.76)$ & & & & \\
\hline WDBPn & 1.62 & 0.77 & .07 & 1 & $(.56)$ & & & \\
\hline WDBPr & 1.39 & 0.72 & -.07 & -.05 & 1 & $(.82)$ & & \\
\hline $\mathrm{TiO}$ & 5.27 & 1.02 & $-.13^{*}$ & -.06 & $.49 *$ & 1 & (.79) & \\
\hline LOC & 5.26 & 0.95 & $-.22 *$ & $-.14 *$ & $.58 *$ & $.63^{*}$ & 1 & (.81) \\
\hline
\end{tabular}

Notes: $\mathrm{N}=355 ;{ }^{*} \mathrm{p}<0.01 ;{ }^{* *} \mathrm{p}<0.05$; Reliabilities are provided in parentheses 
Rahim \& Nasurdin-Trust in Organizational and Workplace Deviant Behavior

As shown in Table 1, the mean score for interpersonal deviance (WDBI) is 1.36 (SD = 0.69). Meanwhile, the mean values for production deviance (WDBPn) and property deviance $(\mathrm{WDBPr})$ are $1.62(\mathrm{SD}=0.77)$ and $1.39(\mathrm{SD}=0.72)$, respectively. In general, the level of WDB for the sample is judged to be low. The respondents' level of trust toward the organization is found to be high (mean $=5.27, \mathrm{SD}=1.02)$. The reliability coefficients for the study variables are acceptable since they comply with Ary et al.’s (2006) requirement.

\section{Regression Results}

\section{The Influence of Trust in Organization on Workplace Deviance}

Table 2 presents the results of the regression analysis between the independent variable (Trust in organization) and the dependent variables (WDBI, WDBPn, and WDBPr). As depicted in Table 2, none of the control variables is found to have a significant impact on the three forms of deviant behavior. Table 2 also demonstrates

Table 2. Results of Regression Analysis: Impact of Trust in Organization on WDB

\begin{tabular}{|c|c|c|c|c|c|c|}
\hline & \multicolumn{2}{|c|}{$\begin{array}{c}\text { Interpersonal } \\
\text { WDB }\end{array}$} & \multicolumn{2}{|c|}{$\begin{array}{c}\text { Production } \\
\text { WDB }\end{array}$} & \multicolumn{2}{|c|}{$\begin{array}{l}\text { Property } \\
\text { WDB }\end{array}$} \\
\hline & $\begin{array}{c}\text { Step } 1 \\
\beta\end{array}$ & $\begin{array}{c}\text { Step2 } \\
\beta\end{array}$ & $\begin{array}{c}\text { Step1 } \\
\beta\end{array}$ & $\begin{array}{c}\text { Step2 } \\
\boldsymbol{\beta}\end{array}$ & $\begin{array}{c}\text { Step1 } \\
\beta\end{array}$ & $\begin{array}{c}\text { Step2 } \\
\beta\end{array}$ \\
\hline \multicolumn{7}{|l|}{ Control Variables } \\
\hline Gender (Male = 1) & .08 & .07 & -.08 & -.07 & -.02 & -.01 \\
\hline Age & .18 & .17 & -.08 & -.07 & .04 & .05 \\
\hline Organizational Tenure & -.12 & -.13 & .18 & .19 & .11 & .11 \\
\hline Job Position & -.01 & -.01 & .08 & .09 & .03 & .05 \\
\hline \multicolumn{7}{|l|}{ Model Variables } \\
\hline Trust in Organization & & $.125 * *$ & & $-.146 *$ & & $-.225 *$ \\
\hline $\mathrm{R}^{2}$ & .019 & .034 & .030 & .051 & .013 & .064 \\
\hline$D \mathrm{R}^{2}$ & & .016 & - & .021 & - & .051 \\
\hline$D F$ & 1.436 & 4.845 & 2.48 & 7.09 & 1.041 & 17.382 \\
\hline$D$ Sig. $F$ & .222 & .028 & .046 & .005 & .386 & .000 \\
\hline
\end{tabular}

Notes: $\mathrm{N}=355 ;{ }^{*} \mathrm{p}<0.01,{ }^{* *} \mathrm{p}<0.05$ 
Gadjah Mada International Journal of Business, May - August 2008, Vol. 10, No. 2

that the model variables explain 3.4 percent of the variation in $\operatorname{WDBI}\left(D \mathrm{R}^{2}=\right.$ $0.016, \mathrm{p}<.05$ ). Trust in organization, however, shows a positive and significant relationship (b $=0.125, \mathrm{p}<.05)$ with WDBI that is contrary to what is hypothesized. Thus, H1a is not supported.

Table 2 also indicates that the model variables explain 5.1 percent of the variation in WDBPn $\left(D \mathrm{R}^{2}=0.021\right.$, $\mathrm{p}<.01$ ), and explain 6.4 percent of the variation in $\operatorname{WDBPr}\left(D \mathrm{R}^{2}=0.051, \mathrm{p}<\right.$ .01). In accordance to H1b, trust in organization is found to have a negative and significant relationship with both WDBPn $(\mathrm{b}=-0.146, \mathrm{p}<.01)$ and WDBPr $(b=-0.225, \mathrm{p}<.01)$.

\section{The Moderating Effect of Locus} of Control

Table 3 illustrates the results of the hierarchical regression analysis on the moderating effect of locus of control between trust in organization and WDBI.

As shown in Table 3, all control variables have no significant relationship with WDBI. Trust in organization (TiO) reveals a significant relationship with the dependent variable in step $2(\mathrm{~b}=.225, \mathrm{p}<.01)$, step $3(\mathrm{~b}=.218$, $\mathrm{p}<.01)$ and step $4(\mathrm{~b}=.210, \mathrm{p}<.01)$. In contrast, no significant relationship is discovered between LOC and WDBI in step 3 and step 4. However, in step

Table 3. Moderating Effect of Locus of Control on the Relationship between Trust in Organization and Interpersonal Deviance

\begin{tabular}{|c|c|c|c|c|c|c|}
\hline $\begin{array}{c}\text { Dependent } \\
\text { Variable }\end{array}$ & $\begin{array}{c}\text { Control } \\
\text { Variables }\end{array}$ & $\begin{array}{c}\text { Independent } \\
\text { Variables }\end{array}$ & $\begin{array}{l}\text { Std Beta } \\
\text { Step } 1\end{array}$ & $\begin{array}{c}\text { Std Beta } \\
\text { Step } 2\end{array}$ & $\begin{array}{c}\text { Std Beta } \\
\text { Step } 3\end{array}$ & $\begin{array}{c}\text { Std Beta } \\
\text { Step } 4\end{array}$ \\
\hline Interpersonal & Gender & & .026 & .007 & .006 & .002 \\
\hline Deviance & Age & & -.085 & -.098 & -.095 & -.113 \\
\hline Org. Tenure & & .036 & .028 & .023 & .034 & \\
\hline \multirow[t]{7}{*}{ Job Position } & & -.044 & -.040 & -.051 & -.046 & \\
\hline & $\mathrm{TiO}$ & & $.225 *$ & $.218 *$ & $.210^{*}$ & \\
\hline & Moderating & & & & & \\
\hline & LOC & & & .095 & .114 & \\
\hline & Interaction & & & & & \\
\hline & Terms & & & & & \\
\hline & LOC X TiO & & & & $-.141^{* *}$ & \\
\hline$R^{2}$ & & .005 & .055 & .064 & .084 & \\
\hline Adjusted $R^{2}$ & & & .007 & .040 & .046 & .063 \\
\hline$\Delta R^{2}$ & & - & .050 & .009 & .020 & \\
\hline F change & & & .417 & 16.333 & 2.888 & 6.728 \\
\hline Sig. F change & & & .796 & .000 & .100 & .010 \\
\hline
\end{tabular}

Notes: $\mathrm{N}=355 ;{ }^{*} \mathrm{p}<0.01,{ }^{* *} \mathrm{p}<0.05$ 
4, the interaction term ( $\mathrm{LOC} \mathrm{X} \mathrm{TiO)} \mathrm{is}$ found to be significant $(\mathrm{b}=-.144$, $\mathrm{p}$ $<.01)$. In addition, the $R^{2}$ value rises from 0.05 percent in step 2 to 8.4 percent in step 4 . Thus, it can be concluded that LOC moderates the relationship between TiO and WDBI.

The plotted graph used for analyzing the effect of the moderating variable (LOC) on the relationship between $\mathrm{TiO}$ and WDBI is depicted in Figure 1. From Figure 1, it can be observed that as the level of $\mathrm{TiO}$ increases from low to high, the level of WDBI decreases sharply for internals. This suggests that the tendency for internals to display acts of WDBI is low when their TiOs are high. On the other hand, regardless of the level of $\mathrm{TiO}$, the level of WDBI for externals remains the same. This suggests that the tendency for externals to continue displaying acts of WDBI is high regardless of their high level of TiO. Moreover, as shown in Figure 1, the slope for internals is steeper than that for externals. This suggests that the impact of LOC on the relationship between $\mathrm{TiO}$ and WDBI is stronger for internals than externals. Therefore, it can be concluded that the moderating impact of LOC on the relationship between $\mathrm{TiO}$ and WDBI is stronger for internals than externals. Thus, hypothesis H2a is accepted.

Since WDBO is comprised of two dimensions, which are production deviance (WDBPn) and property deviance (WDBPr), our hypotheses are restated as follows:

H2b1: The negative relationship between $\mathrm{TiO}$ and WDBPn is stronger for individuals with internal LOC than individuals with external LOC.

Figure 1. The Impact of Locus of Control on the Relationship between Trust in Organization and Interpersonal Deviance

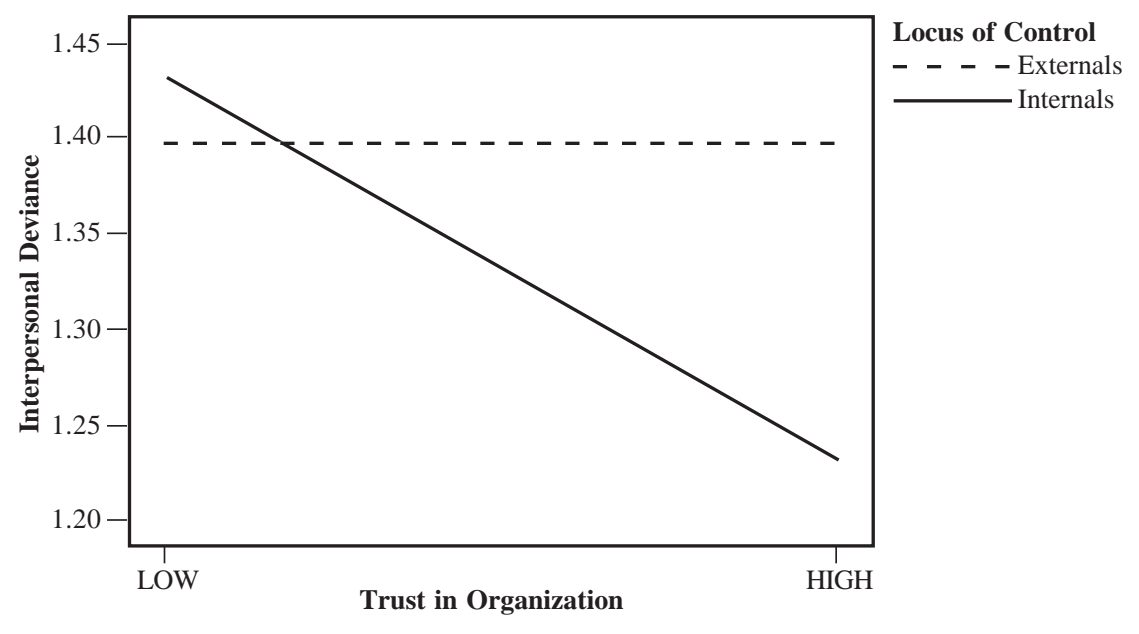


Gadjah Mada International Journal of Business, May - August 2008, Vol. 10, No. 2

H2b2: The negative relationship between TiO and WDBPris stronger for individuals with internal LOC than individuals with external LOC.

Table 4 indicates the hierarchical regression results of the moderating effect of LOC in the relationship between TiO and WDBPn. From Table 4, a significant relationship is observed between $\mathrm{TiO}$ and WDBPn in step 1 (b=-.035, p <.05), step 2 (b=-.027, p $<.05)$ and step $3(b=-.666, p<.05)$. In step 2 and step 3 , it is revealed that LOC does not have any significant and independent effect on WDBPn. On the other hand, the interaction term between $\mathrm{LOC}$ and $\mathrm{TiO}$ is significant $(\mathrm{b}=$ $-.921, \mathrm{p}<.05$ ) in step 3 . The $R^{2}$ value indicates an increase from 3.9 percent in step 1 to 5.7 percent in step 3 . Therefore, it can be surmised that LOC moderates the relationship between the $\mathrm{TiO}$ and production deviance.

Figure 2 indicates the plotted graph used for analyzing the effect of the moderating variable (LOC) on the relationship between $\mathrm{TiO}$ and WDBPn. From Figure 2, it is discovered that the relationship between WDBPn and TiO is negative for internals. As the level of $\mathrm{TiO}$ increases from low to high, WDBPn decreases sharply for internals. This suggests that the higher the level of TiO, the lower the WDBPn demonstrated by internals. In other words, the tendency for internals to display acts of WDBPn is low when their TiOs are high. On the other hand, for externals, they continue to demon-

Table 4. Moderating Effect of Locus of Control on the Relationship between Trust in Organization and Production Deviance

\begin{tabular}{|c|c|c|c|c|c|c|}
\hline $\begin{array}{c}\text { Dependent } \\
\text { Variable }\end{array}$ & $\begin{array}{c}\text { Control } \\
\text { Variables }\end{array}$ & $\begin{array}{c}\text { Independent } \\
\text { Variables }\end{array}$ & $\begin{array}{l}\text { Std Beta } \\
\text { Step } 1\end{array}$ & $\begin{array}{l}\text { Std Beta } \\
\text { Step } 2\end{array}$ & $\begin{array}{c}\text { Std Beta } \\
\text { Step } 3\end{array}$ & $\begin{array}{c}\text { Std Beta } \\
\text { Step } 4\end{array}$ \\
\hline Production & Gender & & -.116 & -.114 & -.114 & -.114 \\
\hline Deviance & Age & & -.037 & -.038 & -.043 & -.051 \\
\hline Org. Tenure & & .181 & .182 & .183 & .178 & \\
\hline \multirow[t]{5}{*}{ Job Position } & & .019 & .012 & -.004 & .001 & \\
\hline & $\begin{array}{c}\text { TiO } \\
\text { Moderating }\end{array}$ & & $-.035^{* *}$ & $-.027 * *$ & $-.666 * *$ & \\
\hline & LOC & & & -.082 & .432 & \\
\hline & Interaction Terms & & & & & \\
\hline & LOC X TiO & & & & $-.921 * *$ & \\
\hline$R^{2}$ & & .039 & .040 & .047 & .057 & \\
\hline Adjusted $R^{2}$ & & & .021 & .019 & .022 & .029 \\
\hline$\Delta R^{2}$ & & - & .001 & .006 & .010 & \\
\hline F change & & & 2.127 & .379 & 2.010 & 3.370 \\
\hline Sig. F change & & & .050 & .043 & .157 & .047 \\
\hline
\end{tabular}

Notes: $\mathrm{N}=355 ;{ }^{*} \mathrm{p}<0.01,{ }^{* *} \mathrm{p}<0.05$ 
Rahim \& Nasurdin-Trust in Organizational and Workplace Deviant Behavior

Figure 2. The Impact of Locus of Control on the Relationship between Trust in Organization and Production Deviance.

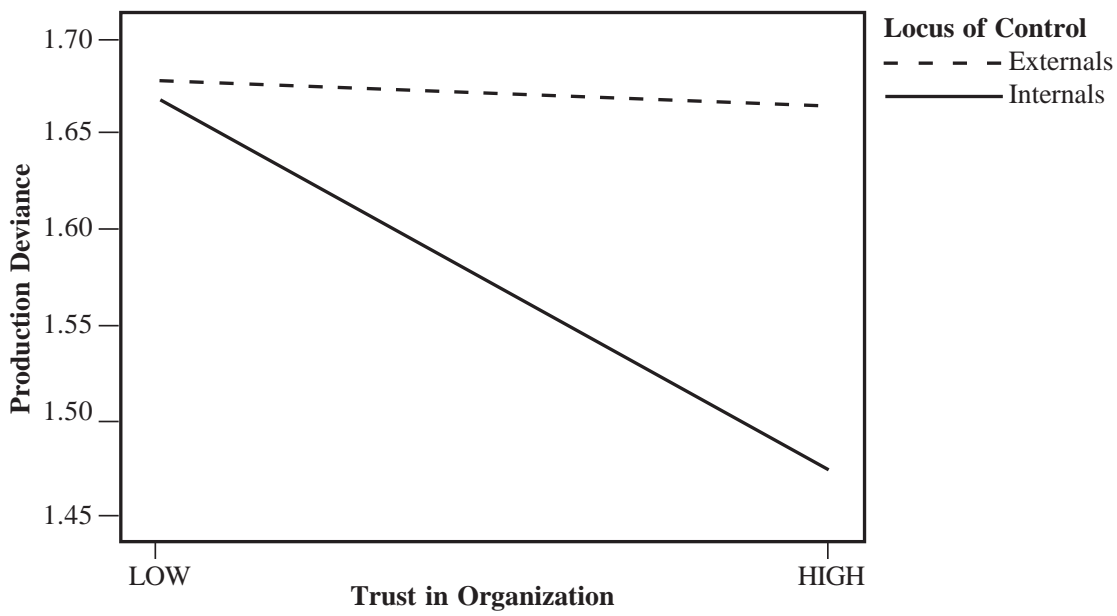

Table 5. Moderating Effect of Locus of Control on the Relationship between Trust in Organization and Production Deviance

\begin{tabular}{|c|c|c|c|c|c|c|}
\hline $\begin{array}{c}\text { Dependent } \\
\text { Variable }\end{array}$ & $\begin{array}{c}\text { Control } \\
\text { Variables }\end{array}$ & $\begin{array}{c}\text { Independent } \\
\text { Variables }\end{array}$ & $\begin{array}{c}\text { Std Beta } \\
\text { Step } 1\end{array}$ & $\begin{array}{c}\text { Std Beta } \\
\text { Step } 2\end{array}$ & $\begin{array}{c}\text { Std Beta } \\
\text { Step } 3\end{array}$ & $\begin{array}{c}\text { Std Beta } \\
\text { Step } 4\end{array}$ \\
\hline Property & Gender & & .093 & .094 & .097 & .092 \\
\hline Deviance & Age & & .097 & .096 & .098 & .113 \\
\hline Org. Tenure & & .106 & .106 & .110 & .109 & \\
\hline \multirow[t]{6}{*}{ Job Position } & & -.258 & -.256 & -.259 & -.263 & \\
\hline & $\mathrm{TiO}$ & & $-.028 *$ & $-.031 *$ & $-.911 *$ & \\
\hline & Moderating & & & & & \\
\hline & LOC & & & $.057 * *$ & $-.622 *$ & \\
\hline & Interaction Terms & & & & & \\
\hline & LOC X TiO & & & & $1.146^{* *}$ & \\
\hline$R^{2}$ & & .222 & .223 & .226 & .240 & \\
\hline Adjusted $R^{2}$ & & & .201 & .198 & .198 & .209 \\
\hline$\Delta R^{2}$ & & - & .001 & .003 & .014 & \\
\hline F change & & & 10.687 & .224 & .919 & 4.233 \\
\hline Sig. F change & & & .000 & .636 & .339 & .014 \\
\hline
\end{tabular}

Notes: $\mathrm{N}=355 ;{ }^{*} \mathrm{p}<0.01,{ }^{* *} \mathrm{p}<0.05$ 
Gadjah Mada International Journal of Business, May - August 2008, Vol. 10, No. 2

Figure 3. The Impact of Locus of Control on the Relationship between Trust in Organization and Property Deviance

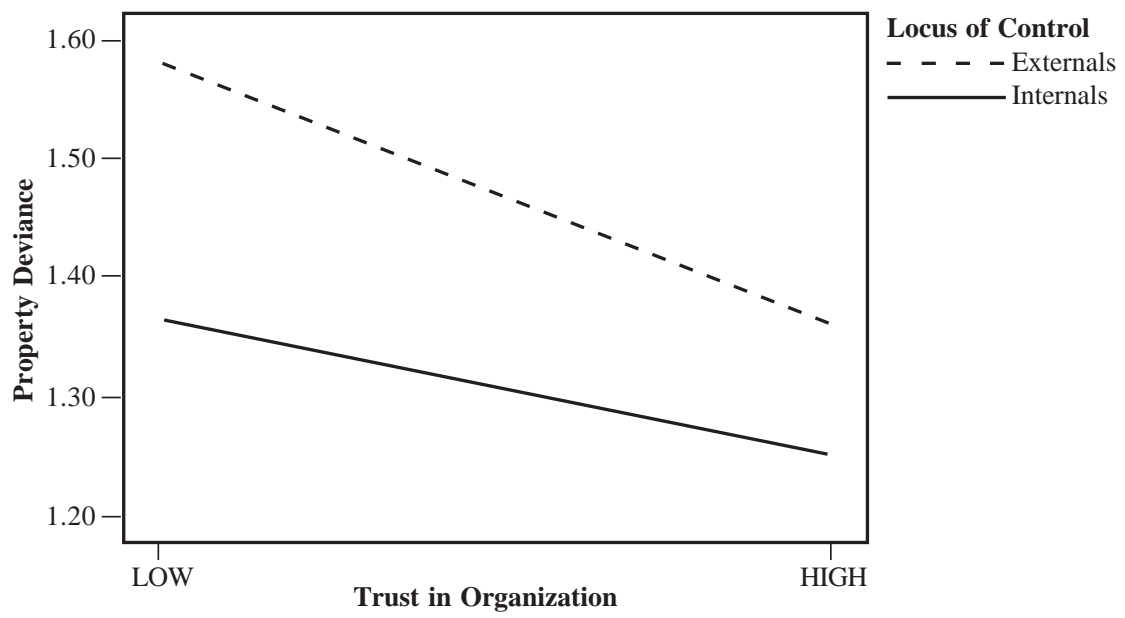

strate acts of WDBPn as their level of TiO increases. As shown in Figure 2, the slope for internals is steeper than that for externals. This suggests that the impact of LOC on the relationship between $\mathrm{TiO}$ and WDBPn is stronger for internals than externals. Therefore, hypothesis H2b is accepted.

The moderating effect of LOC on the relationship between $\mathrm{TiO}$ and WDBPr is depicted in Table 5. From Table 5, it can be seen that TiO indicates a significant and negative relationship with property deviance in step 2 (b = -.028, $\mathrm{p}<.01$ ), step 3 (b = -.031, $\mathrm{p}<.01)$ and step $4(\mathrm{~b}=-.911, \mathrm{p}<.01)$. In step 2 and step 3, LOC is found to have a significant relationship with WDBPr. The interaction terms of LOC and TiO are also significant $(\hat{a}=1.146$, $\mathrm{p}<.05)$. The $R^{2}$ value indicates an increase from 22.2 percent in step 1 to 24 percent in step 3. Hence, LOC is found to act as a quasi moderator be- tween $\mathrm{TiO}$ and WDBPr based on the criteria set by Sharma, Durand, and Gur-Arie (1981).

Figure 3 is provided in analyzing the effect of the moderating variable on the relationship between $\mathrm{TiO}$ and WDBPr. From Figure 3, it can be observed that when the level of $\mathrm{TiO}$ increases from low to high, WDBPr decreases for both internals and externals. The direction of the relationship between $\mathrm{TiO}$ and WDBPr for both internals and externals are identified to be similar. This suggests that the direction of the moderating impact on the relationship between $\mathrm{TiO}$ on WDBPr is similar. Besides, it can be identified that the slope for externals is steeper than that for internals. This suggests that the moderating impact of LOC on the relationship between $\mathrm{TiO}$ and WDBPr is stronger for externals than internals. Therefore, H2b2 is rejected. 
Rahim \& Nasurdin-Trust in Organizational and Workplace Deviant Behavior

\section{Discussion, Implication, Limitations, and Conclusion}

Factor analysis of organizational deviance(WDBO) reveals two dimensions: production deviance (WDBPn) and property deviance (WDBPr), which concur with that of Robinson and Bennett's (1995). On the other hand, interpersonal deviant behavior (WDBI) is found to only have one dimension instead of two as originally identified by Robinson and Bennett (1995). This finding may be culturally bound. According to Abdullah (1992), Malaysian are relationship-oriented and value harmony. Hence, they tend to avoid sensitive interpersonal issues (such as acting rudely toward someone at work, or making ethnic or religious jokes).

This study hypothesizes that $\mathrm{TiO}$ is negatively related to WDBI, WDBPn, and WDBPr. The results of the regression analysis demonstrate significant and negative relationships among TiO, WDBPn, and WDBPr. Our findings illustrate that when employees have high trust in the organization, they are less likely to engage in deviant behavior targeted at the organization's production and properties. As argued by Costa et al. (2001), when employees' trust deteriorates, they will reciprocate to maintain equity. Their acts of deviance targeted toward the organization could be in the forms of efforts withholding, withdrawal, lateness, or intent to leave the organization. Hence, the findings of this research are consistent with ear- lier empirical evidence (Deery et al. 2006; Ferres et al. 2003; Gilder 2003).

In this investigation, a significant and positive relationship is discovered between trust in organization and interpersonal deviance. This finding is contrary to what has been hypothesized. Our findings reveal that the higher the level of employees' trust in organization, the greater will be their level of interpersonal deviant behavior. One possible explanation for the positive TiO-WDBI relationship is as follows. When the employees trust the organization, they expect and believe that the organization will act in a way that is beneficial or at least not detrimental to their employment relationship. As such, they are likely to assume that their display of negative interpersonal behavior, such as making fun or embarrassing someone at the workplace, will most probably be undetected by their employers since there is no likelihood of immediate dysfunctional repercussions on their work performance. In such a situation, employees' whose trust in organization is high will take for granted that interpersonal acts of this nature are considered acceptable and will continue to engage in such behavior.

The pattern of results revealed by the moderating analysis provides support for the hypothesis that locus of control plays a significant role in the attitude-behavior reaction relationship. For externals, a positive relationship is discovered between trust in organization and deviant acts towards interpersonal and production. In other 
words, the higher the externals' trust in organization, the more likely they will engage in interpersonal as well as property deviant behavior. Regardless of high trust in organizations, externals are easily influenced by factors such as actions of their peers and superiors as well as other social pressures. Being externals, they have less developed moral senses and are not able to effectively use information in their decision-making process (Cherry and Freadrich 2000). This inability to process information for performance improvement may lead them to imitate and replicate behavior displayed by others through their learning process and observation. On the other hand, for internals, a negative relationship is found between trust in organization and interpersonal deviance, and production deviance. This reflects that the higher internals' trust in organization, the less likely they will engage in interpersonal as well as property deviant behavior. Internals, with high trust in the organization, believe that their future aspirations and expectations will be fulfilled by the organization. They are more likely to adopt positive work attitudes such as having high job satisfaction and organizational commitment, which will negatively influence their acts of deviance (Cornnelet al. 2003; Ferres et al. 2005). For both internals and externals, a negative relationship is found between trust in organization and property deviance. This suggests that when the externals' and internals' trust in organization is high, their deviance targeted at the organi- zation's properties will be low. However, the negative relationship between WDBPr and TiO is stronger for externals than internals.

Findings of the study confirm the moderating role of locus of control in the relationship between attitude and behavior. It is demonstrated that internals and externals view their working environments differently, which in turn, influences their actual behavior. Such differences occur because of the differences in an individual's self-efficacy, self-consistency, self-esteem, self-monitoring, and expectancies. These differences will shape an individual's ability to control their own actions that will strengthen or weaken the actual behavior. Under the moderating effect of LOC, all hypotheses are supported by related literature (Blau 1987; Chiu et al. 2005; Gable and Dangelo 1994; Storm and Spector 1987). However, the findings on the relationship between trust in organization and deviant behavior as a function of locus of control is found to be inconsistent. This inconsistency in findings may be due to the fact that Malaysian workers' attitude and behavior tend to be influenced by their collectivistic culture. Being a group-oriented society, employee's behavior could be easily influenced by their work-group culture (Abdullah 1992; 1996)

Like all studies, this study has three limitations. First, this study adopts a supervisory rating method in order to reduce common method bias. Consequently, it may be unlikely for supervisors to know all incidences of 
WDB because employees are inclined to be tactful when doing such acts. Future research should adopt a superior-subordinate dyadic method rating to further reduce the extent of common method bias. Second, the characteristics of the sample may limit our ability to generalize the findings. This is because nearly 85 percent of the respondents in this study are Malay relative to other ethnic groups like Chinese and Indian. To avoid any bias, future researchers should ensure an equal distribution of respondents from various ethnic groups. Third, the research design is cross-sectional and the data collected reflect responses for one particular period. In order to further determine employees' trust in organization and the causal attributions made, a longitudinal design may be more appropriate.

In conclusion, despite several limitations, this research provides evidence of how trust in organization can affect employees' deviant behavior at the workplace. Although employees are likely to engage in interpersonal deviant acts when their trust in organization is high, they are unlikely to display such deviant acts targeted at the organization's production and properties. One way of enhancing employees' trust in their organization is by establishing good employee-management relations. Specifically, employees' representatives and management personnel must be honest and sincere in their dealings with one another with respect to problem solving. Besides, the organization should foster strong ethical values and culture in order to reduce the incidences of employees' negative work behavior targeted at the organization. On a similar note, organizational authorities need to be alert to the occurrences of interpersonal deviant behavior, and continue to curb such acts since this negative behavior may culminate in more serious consequences. Furthermore, locus of control is found to moderate the relationship between trust in organization and deviant behavior. For externals, a positive relationship is discovered between trust in organization and deviant acts toward interpersonal and production. In contrast, for internals, a negative relationship is found between trust in organization and interpersonal deviance, and production deviance.

\section{References}

Ackroyd, S., and P. Thomson. 1999. Organizational Misbehavior. Thousand Oak, USA: Sage Publications, Inc.

Adams, J. S. 1965. Inequity in social exchange. In E. L. Berkowitz (Ed.), Advances in Experimental Social Psychology: 267-299. New York: Academic Press.

Allen, D. G., K. P. Weeks, and K. R. Moffitt. 2005. Turnover intentions and voluntary turnover: The moderating roles of self-monitoring, locus of control, proactive personality, and risk aversion. Journal of Applied Psychology 90 (5): 980-990. 
Gadjah Mada International Journal of Business, May - August 2008, Vol. 10, No. 2

Appelbaum, S. H., K. J. Deguire, and M. Lay. 2005. The relationship of ethical climate to deviant workplace behavior. Corporate Governance 5 (4): 43-55.

Aquino, K., B. L. Galperin, and R. J. Bennett. 2004. Social status and aggresiveness as moderator of the relationship between interactional justice andworkplace deviance. Journal of Applied Psychology 34 (5): 1001-1029.

Ary, D., L. C. Jacobs, A. Razaveih, and C. Sorensen. 2006. Introduction to Research in Education ( $7^{\text {th }}$ ed.). Canada: Thomson Wadsworth. .

Banai, M., W. D. Reisel, and T. M. Probst. 2004. A managerial and personal control model: Predictors of work alienation and organizational commitment in Hungary. Journal of International Management 10: 375-392.

Baron, R. A., and J. H. Neuman. 1998. Workplace aggression - The iceberg beneath the tip of workplace violence: Evidence on its forms, frequency and targets. Public Administration Quarterly 21 (4): 446-464.

Bennett, R. J., and S. L. Robinson. 2000. Development of a measure of workplace deviance. Journal of Applied Psychology 85 (3): 349-360.

Bies, R. J., and T. M. Tripp. 1996. Beyond distrust: "Getting even” and the need for revenge. In R. M. Kramer and T. R. Tyler (Eds.), Trust in Organizations. London: Thousand Oaks.

Blau, G. J. 1987. Locus of control as a potential moderator of the turnover process. Journal of Occupational and Organizational Psychology 60 (1): 21-29.

Bolin, A., and L. Heatherly. 2001. Predictors of employee deviance: The relationship between bad attitudes and bad behavior. Journal of Business and Psychology 15 (3): 405-418.

Brown, M. E., and L. K. Trevino. 2003. The influence of leadership styles on unethical conduct in work groups. Paper (Best Paper Proceedings) presented at the Academy of Management Conference. Seattle.

Carmeli, A. 2005. The relationship between organizational culture and withdrawal intentions and behaviours. International Journal of Man Power 26 (2): 177-195.

Chen, P. Y., and P. E. Spector. 1992. Relationships of work stressors with aggression, withdrawal, theft and substance abuse: An exploratory study. Journal of Occupational and Organizational Psychology 65: 177 - 184.

Cherry, J., and J. Fraedrich. 2000. An empirical investigation of locus of control and the structure of moral reasoning: Examining the ethical decision-making processes of sales managers. Journal of Personal Selling and Sales Management 20 (3): 173-188.

Chiu, C. K., C-S. Chien, C. P. Lin, and C. Y. Hsio. 2005. Understanding hospital employee job stress and turnover intentions in a practical setting. Journal of Management Development 24 (10): 837-855.

Colbert, A. E., M. K. Mount, J. K. Harter, L. A. Witt, and M. R. Barrik. 2004. Interactive effects of personality and perceptions of the work situation on workplace deviance. Journal of Applied Psychology 89 (4): 559-609.

Cook, K. S. 2005. Networks, norms and trust: The social psychology of social capital. Social Psychology Quarterly 68 (1): 4-14. 
Rahim \& Nasurdin-Trust in Organizational and Workplace Deviant Behavior

Costa, A. C. 2003. Understanding the nature and the antecedents of trust within work teams. In B. Nooteboom and F. Six (Eds.), The Trust Process in Organizations: 105124. UK: Edwar Edgar Publishing Limited.

Deery, S. J., R. D. Iverson, and J. T. Walsh. 2006. Toward s better understanding of psychological contract breach: A study of customer service employees. Journal of Applied Psychology 91 (1): 166-175.

Diefendorff, J. M., and K. Mehta. 2007. The relations of motivational traits with workplace deviance. Journal of Applied Psychology 92 (4): 967-977.

Douglas, S. C., and M. J. Martinko. 2001. Exploring the role of individual differences in predicting of workplace aggression. Journal of Applied Psychology 86 (4): 547-559.

Dreu, C. K. W. D., E. Giebels, and E. V. d. Vliert. 1998. Social motives and trust in integrative negotiation: The distruptive effects of punitive capability. Journal of Applied Psychology 83 (3): 408-422.

Ferres, N., J. Connel, and A. Travaglione. 2005. The effect of future redeployment on organizational trust. Journal of Strategic Change 14 (2): 77-92.

Firth, L., D. J. Mellor, K. A. Moore, and C. Loquet. 2004. How can managers reduce employees intention to quit. Journal of Managerial Psychology 19 (2): 170-187.

Fox, S., P. E. Spector, and D. Miles. 2001. Counterproductive work behavior in response to job stressors and organizational justice: Some mediator and moderator tests for autonomy and emotions. Journal of Vocational Behavior 59 (3): 291-309.

Gabarro, J., and J. Athos. 1976. Interpersonal Relations and Communications. Engliwood Cliffs, NJ: Prentice-Hall.

Gable, M., and F. Dangello. 1994. Locus of control, machiavellianism, and managerial job performance. Journal of Psychology 128 (5): 599-608.

Ganster, D. G., and J. J. Schaubroeck. 1991. Work stress and employee health. Journal of Management 17 (2): 235-271.

Giacalone, R. A., and J. Greenberg. 1997. Antisocial Behavior in Organizations. London. UK: SAGE Publications, Inc.

Gilder, D. d. 2003. Commitment, trust and work behavior. Personnel Review 32 (5): 588604.

Goris, J. R., B. C. Vaught, and J. D. Pettit. 2003. Effects of trust in superiors and influence of superiors on the association between individual-job congruence and job performance/satisfaction. Journal of Business and Psychology 17 (3): 327-343.

Greenberg, J. 1997. The steal motive: Managing the social determinants of employee theft. In R. A. Giacalone and J. Greenberg (Eds.), Antisocial Behavior in Organizations. London, UK: Sage Publications, Inc.

Greenberg, J. 2002. Who stole the money, and when? Individual and situational determinants of employee theft. Organizational Behavior and Human Decision Process 89 (1): 985-1003.

Greenberg, J., and B. J. Algae. 1998. Aggressive reactions to workplace injustice. In R. W.Griffin, A. O’Leary-Kelly and J. M.Collins (Eds.), Dysfunctional behavior in organization 23: 83-117. Greenwich: CT:JAI. 
Gadjah Mada International Journal of Business, May - August 2008, Vol. 10, No. 2

Grover, S. L. 1997. Lying in organizations: Theory, research, and future directions. In R. A. Giacalone and J. Greenberg (Eds.), Antisocial Behavior in Organizations. London, UK: Sage Publications, Imc.

Harris, M. M. 2004. Alcohol and drug use in the workplace. In R. W. Griffin and A. M. O'Leary-Kelly (Eds.), The Dark Side of Organizational Behavior: 341-372. San Fransisco, USA: John Wiley and Sons.

Hegarty, H. W., and H. P. J. Sim. 1978. Some determinants of unethical decision behavior: An experiment. Journal of Applied Psychology 63 (4): 451-457.

Hegarty, H. W., and H. P. J. Sim. 1979. Organizational philosophy policies and objectives related to unethical decision behavior: A laboratory experiment. Journal of Applied Psychology 64 (4): 331-338.

Hollinger, R. C. 1986. Acts against the workplace: Social Bonding and employee deviance. Deviant Behavior 7: 53-75.

Johns, G. 1997. Contemporary research on absence from work: Correlates, causes and consequences. In C. L. Cooper and I. T. Roberston (Eds.), Key Issues in Industrial and Organizational Behavior. New York: John Wiley and Sons Ltd.

Jones, G. E., and M. J. Kavanagh. 1996. An experimental examination of the effects of individual and situational factors on unethical behavior intentions in the workplace. Journal of Business Ethics 15 (5): 511-523.

Judge, T. A., and J. E. Bono. 2000. Five-factor model and transformational leadership. Journal of Applied Psychology 85 (5): 751-765.

Konovsky, M. A., and R. Cropanzano. 1991. Perceived fairness of employee drug testing as predictor of employee attitudes and job performance. Journal of Applied Psychology 76 (5): 698-707.

Kramer, R. M., M. B. Brewer, and B. A. Hanna. 1996. Collective trust and collective action: The decision to trust as a social decision. In R. M. Kramer and T. R. Tyler (Eds.), Trust in Organization: 357-389. London: Sage Publications Inc.

Lau, V. C. S., W. T. Au, and J. M. C. Ho. 2002. A qualitative and quantitative review of antecedents of counterproductive behavior in organizations. Journal of Business and Psychology 18 (1): 73-99.

Lewicki, R. J., and B. B. Bunker. 1996. Developing and maintaining trust in work relationship. In R. M. Kramer and T. R. Tyler (Eds.), Trust in Organizations: 114139. London: Sage Piblication Inc.

Lonergan, J. M., and K. J. Maher. 2000. The relationship between job characteristics and workplace procrastination as moderated by locus of control. Journal of Social Behavior and Personality 15 (5): 213-224.

Lu, L., H-L. Wu, and C. L. Cooper. 1999. Perceived work stress and locus of control: A combined quantitative and qualitative approach. Research and Practice in Human Resource Management 7 (1): 1-15.

Marcus, B., and H. Schuler. 2004. Antecedents of counterproductive behavior at work: A general perspective. Journal of Applied Psychology 89 (4): 647-660. 
Rahim \& Nasurdin-Trust in Organizational and Workplace Deviant Behavior

Martinko, M. J., M. J. Gundlach, and S. C. Douglas. 2002. Toward an integrative theory of counterproductive workplace behavior: A causal reasoning perspective. International Journal of Selection and Assessment 10 (1/2): 36 - 50.

McShane, S. L., and M. A. V. Glinow. 2003. Organizational behavior. New York: McGraw Hill.

Murphy, K. R. 1993. Honesty in the Workplace. Belmont, CA: Brooks/Cole.

Nooteboom, B. 2003. The trust process. In B. Nooteboom and F. Six (Eds.), The Tust Process in Organizations. Cheltenham, UK: MPG Books Ltd.

O’Leary-Kelly, A. M., and R. W. Griffin. 2004. Dark side issues: Concluding observations and directions for future research. In R. W. Griffin and A. M. O’Leary-Kelly (Eds.), The Darkside of Organizational Behavior: 462-486. San Fransisco, USA: John Wiley and Sons.

Paetzold, R. L. 2004. Sexual harassment as dysfunctional behavior in organizations. In R. W. Griffin and A. M. O’Leary-Kelly (Eds.), The Dark Side of Organization. San Francisco: Jossey-Bass.

Perry, R. W., and L. D. Mankin. 2004. Understanding employee trust in management: Conceptual clarification and correlates. Public Personnel Management 33 (3): 277290.

Premeaux, S. F., and A. G. Bedeian. 2003. Breaking the silence: The moderating effects of self-monitoring in predicting speaking up in the workplace. Journal of management Studies 40 (6), 1537-1562.

Raelin, J. A. 1984. An examination of deviant/adaptive behaviors in the organizational careers of professionals. Academy of Management Review 9 (3): 413-427.

Reiss, M. C., and K. Mitra. 1998. The effects of individual difference factors on the acceptability of ethical and unethical workplace behaviors. Journal of Business Ethics 17 (14): 1581- 1593.

Robbins, S. P. 2003. Organizational Behavior ( $9^{\text {th }}$ ed.). New Jersey: Prentice Hall.

Roberts, J. A., R. S. Lapidus, and L. B. Conko. 1997. Salespeople and stress: The moderating role of locus of control on work stressors and felt stress. Journal of Marketing Theory and Practice 5 (3): 93-107.

Roberts, K. H., and C. A. O’Reilly. 1974. Failures in upward communication in organizations: Three possible culprits. Academy of Management Journal 37 (3): 656-669.

Robinson, S. L., and R. J. Bennett. 1995. A typology of deviant workplace behaviors: A multidimensonal scaling study. Academy of Management Journal 38 (2): 555-564.

Robinson, S. L., and D. M. Rousseau. 1994. Violating the psychological contract:: Not the exception but the norm. Journal of Organizational Behavior 15 (3): 245-259.

Rose, R. L., and J. F. Veiga. 1984. Assessing the sustained effects of a stress management intervention on anxiety and locus of control. Academy of Management Journal 27 (2): 190-198.

Rusbult, C. E., D. Farrell, G. Rogers, and A. G. Mainous. 1988. Impact of exchange variables on exit, voice, loyalty and neglect: An integrated model of responses to decline job satisfaction. Academy of Management Journal 31 (3): 599-627. 
Gadjah Mada International Journal of Business, May - August 2008, Vol. 10, No. 2

Sackett, P. R. 2002. The structure of counterproductive work behavior: Dimensionality and relationships with facets of job performance. International Journal of Selection and Assessment 10 (1/2): 5-11.

Skarlicki, D. P., and R. Folger. 1997. Retaliation in the workplace: The roles of distributive, procedural and interactional justice. Journal of Applied Psychology 82 (3): 434-443.

Spector, P. E. 1988. Development of the work locus of control scale. Journal of Occupational and Organizational Psychology 61 (4): 335 - 340.

Spector, P. E., and S. Fox. 2002. An emotion centred model of voluntary work behavior: Some parallels between counterproductive work behavior and organizational citizenship behavior. Human Resource Management Review 12 (2): 269-292.

Spector, P. E., and S. M. Jex. 1991. Relations of job characteristics from multiple data sources with employee affect, absence, turnover intentions, and health. Journal of Applied Psychology 76 (1).

Spector, P. E., and B. J. O’Connell. 1994. The contribution of personality traits, negative affectivity, locus of control and Type A to the subsequent reports of job stressors and job strains. Journal of Occupational and Organizational Psychology 67 (1): 1-11.

Storms, P. L., and P. E. Spector. 1987. Relationships of organizational frustration with reported behavioral reactions of employees: The moderating role of locus of control. Journal of Occupational Psychology 60: 227-234.

Syrotnick, J. M., and C. D’Arcy. 1982. Occupational stress, locus of control and health among men in a Prairie Province. Canadian Journal of Behavioral Science 14 (2): 122-133.

Tepper, B. J. 2000. Consequenses of abusive supervision. Academy of Management Journal 43 (2).

Thoms, P., P. Wolper, K. S. Scott, and D. Jones. 2001. The relationship between immediate turnover and employee theft in the restaurant industry. Journal of Business and Psychology 15 (4): 561-577.

Turnley, W. H., and D. C. Feldman. 1999. The impact of psychological contract violation on exit, voice, loyalty and neglect. Human Relations 52 (7): 895-922.

Vardi, Y. 2001. The effects of organizational and ethical climates on misconduct at work. Journal of Business Ethics 29(4): 325 - 338.

Vardi, Y., and Y. Wiener. 1996. Misbehavior in organizations: A motivational framework. Organizational Science 7 (2): 151-165.

Vardi, Y., and E. Weitz. 2004. Misbehavior in Organizations: Theory, Research, and Management. NJ: London: Lawrence Erlbaum Associates.

Vigoda, E. 2002. Stress-related aftermaths to workplace politics: The relationships among politics, job distress and aggressive behavior in organizations. Journal of Organizational Behavior 23 (5): 571-589.

Withey, M. J., and W. H. Cooper. 1989. Predicting exit, voice, loyalty, and neglect. Administrative Science Quarterly 34 (4): 521-539. 
Rahim \& Nasurdin-Trust in Organizational and Workplace Deviant Behavior

Wong, Y.-T., C-S. Wong, and H.-Y. Ngo. 2002. Loyalty to supervisor and trust in supervisor of workers in Chinese joint ventures: A test of two competing models. The International Journal of Human Resource Management 13 (6): 883-900.

Zahra, S. A. (1989). Executives values and ethics of company politics.Journal of Business Ethics 8 (1): 15-29.

\section{Others References:}

Industrial Law Reports. 2000-2005. The Malaysian Current Law Journal Sdn Bhd. Kuala Lumpur, Malaysia.

New Straits Times. 2005. 3,000 Work Fatalities a Day (September 4).

New Straits Time. 2005. Short Changed by Civil Servants’ Poor Work Attitude. (August 31).

Ninth Malaysia Plan 2006-2010. 2006. The Econimic Planning Unit, Prime minister's Department. Retrieved. from http://www.jpm.my/rm9/html

SOCSO. 2003. Annual Report. Kuala Lumpur, Malaysia: Social Security Organization.

Utusan Malaysia. 2004. Jenayah Perdagangan Libatkan Kerugian RM79 Juta Tahun Lalu. (July 7). 